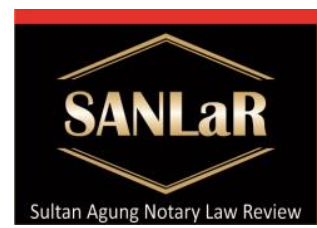

\title{
Accontability of a Notary Public Credit Agreement Signing Process
}

\section{Octovindo Baharano*)}

*) Students of Master of Notary Law, Faculty of Law, Universitas Islam Sultan Agung (UNISSULA) Semarang, E-mail: vbaharano@gmail.com

\begin{abstract}
The role of a notary in making a bank credit agreement deed is very important in making a credit agreement deed. The purpose of this study is to determine and analyze the validity of a bank credit agreement and the accountability of a notary to the parties if the credit agreement signing process cannot be carried out in accordance with Act No. 2 of 2014 concerning Amendments to the Laws and Regulations Number 30 of 2004. regarding the Position of Notary Public. The approach to the problem that will be used in this thesis is a normative juridical approach. The validity of a bank credit agreement is adjusted to the legal terms of the agreement according to Article 1320 of the Civil Code, namely agreement, competence, lawful causes, and certain matters. The form and format shall be submitted by Bank Indonesia to the respective bank to determine it, however in safeguarding measures, at least it must pay attention to the following matters: Fulfilling the legality and legal requirements that can protect bank interests and Contain the amount, period, procedure repayment of credit and other credit terms as stipulated in the said credit approval decision. The responsibility of a notary is only limited to the process of implementing the credit agreement, only to the actions taken whether it is in accordance with the procedure or not, not to the administrative nature. Fulfills the legality and legal requirements that can protect the interests of the bank and contains the amount, period, procedure for repayment of credit and other credit requirements as stipulated in the credit approval decision. The responsibility of a notary is only limited to the process of implementing the credit agreement, only to the actions taken whether it is in accordance with the procedure or not, not to the administrative nature. Fulfills the legality and legal requirements that can protect the interests of the bank and contains the amount, period, procedure for repayment of credit and other credit terms as stipulated in the credit approval decision. The responsibility of a notary is only limited to the process of implementing the credit agreement, only to the actions taken whether it is in accordance with the procedure or not, not to the administrative nature.
\end{abstract}

Keywords: Liability; Notary; Credit Agreement.

\section{Introduction}

Notary as a public official who has the authority to make an Authentic Deed can be held responsible for his actions in connection with his work in making the 
Deed. The scope of the Notary's responsibility includes the material correctness of the Deed he makes, namely: ${ }^{1}$

1. The responsibility of a notary in civil terms of the material correctness of the Deed he makes.

2. The responsibility of the Notary Criminally regarding the material truth in the Deed he makes.

3. The responsibility of a Notary based on the Notary Position Regulation regarding the correctness of the material in the Deed he makes.

4. The notary's responsibility in carrying out his/her job duties is based on the Notary's code of ethics.

The role of a notary in making bank credit agreement deeds is very important where notaries as public officials are required to be professional, one of which is bridging the interests of creditors and debtors in making credit agreement deeds. However, the reality is that this professional attitude is faced with the demands of the banking world, namely: efficiency of banking procedures and security in providing credit, so that in practice banking institutions tend to use standard agreements in their credit agreements. ${ }^{2}$

The existence of a notary is inseparable from the community's need for the importance of strong evidence in every legal event. Notaries carry out their duties and positions to the community properly. This can only be done if the notary behaves and is guided in accordance with what is stated in the Law on Notary Position and the Notary's Code of Ethics. Both of these provisions are equipped with strict sanctions for violators. ${ }^{3}$

In making an agreement, the notary must be guided by the provisions of the applicable laws. However, although making an authentic deed is the authority of the notary public, when the bank uses the services of a notary in making a credit agreement, the bank will generally ask the notary to adhere to standard bank clauses. $^{4}$

\footnotetext{
${ }^{1}$ Herlien Budiono, 2013, Collection of Civil Law Writing in the Notary Sector, Citra Aditia Bakti, Bandung, p. 33

${ }^{2}$ Gunarto Suwandi, 2006, Risks in Providing Banking Credit, Projustitia Legal Journal. January 2006, Volume 24 No. 1, h. 2

${ }^{3}$ Wirjono Prodjodikoro, 2000, Unlawful Acts, Mandar Maju, Bandung, pp. 6-7.

${ }^{4}$ Mariah Kamelia, Anis Mashdurohatun, The Role of Notaries in Making Credit Agreement Deeds in the Perspective of Positive Law and Islamic Law, Akta Journal, ol. 4 No. 4 December 2017, p. 577
} 
From the background description that the author has described, the author is interested in further and deeper study of the Notary's responsibility for the Bank's credit agreement deed by taking the title Notary Responsibility in Making Bank Credit Agreements in terms of the provisions of Act No. 30 of 2004 jo. Act No. 2 of 2014 concerning Notary Position.

Based on the description of the background that has been presented, the authors formulate the following problems:

1. How is the validity of the bank credit agreement in terms of Act No. 2 of 2014 concerning Amendments to the Prevailing Laws Number 30 of 2004 concerning the Position of Notary Public?

2. What is the responsibility of a notary to the parties if in the process of signing a credit agreement it cannot be carried out in accordance with Act No. 2 of 2014 concerning Amendments to the Prevailing Laws Number 30 of 2004 concerning the Position of a Notary?

\section{Research methods}

The approach to the problem that will be used in this thesis is a normative juridical approach. For this reason, research is needed which is a main plan in the development of science. The normative juridical approach is an approach that is carried out based on the main legal material by examining theories, concepts, legal principles and laws and regulations related to this research. ${ }^{5}$ The research specification used is descriptive analysis, namely research that aims to provide an overview of the problems that occur in connection with the use of applicable laws and regulations and relevant theories and then collected through data that is collected, processed, and theoretically arranged in order to obtain a solution problem according to applicable regulations. ${ }^{6}$

\section{Results and Discussion}

\subsection{Realization of the Legality of Bank Credit Agreements}

Based on UUJN, Notary is intended to assist and serve people who need authentic written evidence regarding circumstances, events, or legal actions. Notary as a general official has the authority to make authentic deeds including all the actions regulated in Act No. 2 of 2014 on Amendment to Act No. 30 of 2004 concerning the Position of Notary Public as long as it does not conflict with the elements and the legal conditions of the agreement in article 1320. Civil Code and its legal requirements and terms of agreement (contract). The valid terms of the agreement based on Article 1320 of the Civil Code, include:

\footnotetext{
${ }^{5}$ Soerjono Soekanto \& Sri Mamudji, 2001, Normative Legal Research (A Brief Overview), Rajawali Pers, Jakarta, p. 13-14.

${ }^{6}$ Sri Sumawarni, 2012, A Series of Legal Research Methods, UPT UNDIP Press, Semarang, p. 6
} 


\section{1) Deal}

One of the essentials of contract law is their agreement that binds themselves or other names is the principle of consensualism. The principle of consensualism contained in Article 1320 of the Civil Code has the meaning of "willingness" of the parties to bind themselves to one another. The agreement is meant here is the agreement of the will between the parties, namely the meeting between supply and demand. ${ }^{7}$ The principle of consensualism can be concluded in Article 1320 paragraph (1) of the Civil Code. In this article, it is determined that one of the conditions for the validity of the agreement is the existence of a word of agreement between the two parties. This principle is a principle which states that agreements in general are not formally held, but only if there is an agreement between the two parties. Agreement is the agreement between the will and the statement made by both parties. The principle of consensualism was inspired by Roman law and German law. In German books the term consensualism principle is not known, but it is better known as a real agreement and a formal agreement. ${ }^{8}$

Article 1321 of the Civil Code stipulates that an agreement must be given freely. Free as referred to in Article 1321 of the Civil Code is that there is no coercion, fraud, and error. The Civil Code recognizes the intention that arises from the person concerned or is usually referred to as a defect of the will. Article 1321 of the Civil Code determines three elements of a will defect, namely as follows:

a. Mistakes/dwaling: determined in Article 1322 of the Civil Code. an error is deemed to exist if the statement is in accordance with the will but the intended will is based on an erroneous image of either the person (error in persona) or the object (error in substantia). The character of this error is that there is no influence from other parties. Example: Person A buys an original book by Pramoedya Ananta Toer. However, after studying and researching it turned out that the book he bought was a fake Pramoedya Ananta Toer. Si A wanted to invite Rare Kual comedian to his show but when the stage was real it was Rare Kuwal.

b. Coercion/dwang: specified in Articles 1323-1327 of the Civil Code. Coercion occurs not because of one's own desire but because of the influence of others. Article 1324 of the Civil Code provides that "coercion has occurred, if the act is in such a way as to cause fear in the person that he or his assets are threatened with real loss". An example is a person who signs an agreement with the excuse that if he does not sign then that person will be disabled for the rest of his life.

\footnotetext{
${ }^{7}$ Ahmadi Miru and Sakka Pati, 2008, Bond Law: Explanation of the Meaning of Articles 1233 to 1456 BW, Cet III, Rajagrafindo Persada, Jakarta, p. 68.

8Jamal Wiwoho and Anis Mashdurohatun, 2017, Contract Law, Sharia Economics and Business Ethics, Undip Press, Semarang, p. 23
} 
Elly Erawati and Herlien Budiono emphasized that coercion in the Civil Code is psychological or spiritual coercion, ${ }^{9}$

c. Fraud/Bedrog: an agreement must be carried out in good faith (goodfaith) as stipulated in Article 1338 paragraph (3) of the Civil Code. If one of the parties who entered into the agreement had bad intentions or intentions, then that party from the beginning had the intention to commit fraud in an agreement. fraud committed by one of the parties or the parties, of course, does not meet the legal requirements of the agreement. the fraudster must be able to prove its elements and forms, if in general the agreement is not fulfilled by the presence of an element of fraud, then the agreement can be canceled. If one of the parties does not agree with the agreement made with the element of fraud, the other party can cancel it due to neglect of the subjective condition, namely the agreement. ${ }^{10}$

\section{2) Proficiency}

The parties who make an agreement must have the ability to take legal actions. everyone who is an adult and is not placed under interdiction, has met the competent criteria. An action in order to have a perfect legal effect, then the person who acts when the action is carried out must have maturity to think normally, meaning that he is able to fully realize his actions and the consequences of that action.

Everyone has the ability to make an agreement, unless by law it has been determined to be incompetent. Article 1330 of the Civil Code specifies the following criteria for persons incapable of entering into an agreement:

a. People who are not yet adults (Article 330 of the Civil Code)

b. People who are placed under interdiction (Article 452 of the Civil Code)

c. Married woman

\section{3) A certain thing}

A certain thing in the terms of the validity of the agreement means that the object of the agreement must be clear and determined by the parties. The object of the agreement can be in the form of goods or services but can also be in the form of not doing something. ${ }^{11}$ Articles 1332, 1333, and 1334 of the Civil Code determine the object of the agreement including the following:

a. Can be traded;

\footnotetext{
${ }^{9}$ Elly Erawati and Herlien Budiono, 2010, Legal Explanation of Agreement Cancellation, PT Gramedia, Jakarta, p. 56.

${ }^{10}$ Abdulkadir Muhammad, 2014, Indonesian Civil Law, Cet V, Citra Aditya Bhakti, Bandung, p. 102

${ }^{11}$ Ratna Artha Windari, 2014, Agreement Law, Graha Ilmu, Yogyakarta, p. 17.
} 
b. Determined the type (clearly the type);

c. The number of items can be counted or determined;

d. These items will be there at a later date;

e. Not an unopened legacy.

If services are used as the object of the agreement, it must be clearly and firmly determined what form of service is performed by one of the parties. ${ }^{12}$ If the object of the agreement is not doing something, it must be explained in the agreement what the parties have not done. ${ }^{13}$

\section{4) Because that is lawful}

A lawful cause means that the contents of the agreement, the objectives of the agreement to be achieved by the parties are not against the law, do not conflict with public order and do not conflict with morality as stipulated in Article 1337 of the Civil Code. An agreement that is made without cause or that is made because of some false or forbidden cause.

The valid terms of the agreement as described by the author as a first step in making an agreement and so that the agreement made can be declared valid according to law, it must meet the legal requirements of the agreement as regulated in Article 1320 of the Civil Code.

Banking credit agreement arrangements are not found in Chapter V to Book III of the Civil Code, from various types of agreements there are no provisions on bank credit agreements, Book III of the Civil Code only regulates money lending and borrowing agreements, not specifically mentioning bank credit agreements. Even in the Banking Act itself does not recognize the term bank credit agreement, the term bank credit agreement is found in Government instructions, which are addressed to the public or bank customers. were instructed that in providing credit of any kind, banks are required to use a "credit agreement agreement".

The legal basis regarding the necessity for a credit agreement in bank credit appears in Article 1 number 11 and number 12 of Act No. 10 of 1998 concerning Banking, which states that credit is given based on a loan agreement between a bank and another party.

Mariam Darus Badrulzaman stated that credit has the meaning, among others, first, as the basis of every engagement (verbintennis), where a person has the right to demand something from others. Second, as a guarantee, a person gives something to someone else with the aim of getting back what was given up.

\footnotetext{
${ }^{12}$ Ibid, p. 18

${ }^{13}$ Ibid.
} 
Furthermore, Thomas Suyatno formulated that credit is the voluntary handing over of an amount of money to be used freely by the recipient of the credit. The credit recipient has the right to use the loan to his advantage with the obligation to return the loan amount at a later date.

\subsection{The Accountability of a Notary Public in the Signing Process of a Credit Agreement Cannot Be Implemented in Accordance with the Laws and Regulations Number 2 of 2014 concerning Amendments to the Laws and Regulations Number 30 of 2004 concerning the Position of Notary}

According to the Surabaya District Court Decision, number 260/Pid.B/1981/PN Sby, dated January 1, 1984, Surabaya High Court, number 127/Pid/1984/PT, Sby, dated July 5, 1984 and the Supreme Court number 942/Pid/1984, September 28, 1985, as well as the Surabaya High Court, number 270/Pid/1984/PT.Sby, dated April 14, 1986, a verdict on the subject matter, that the making of the party deed, the notary was only concerned with what the party wanted or wanted. the party concerned, by taking notes, then compiling it in accordance with the applicable legal regulations, and when it is finished with the wishes of the party tappers, then the applicants are asked to sign his/her and write his/her full name, this is the procedure for making a Notary deed of a party's deed. ${ }^{14}$

Notary as a public official who has the authority to make an Authentic Deed can be held responsible for his actions in connection with his work in making the Deed. The scope of the Notary's responsibility includes the material correctness of the Deed he makes, namely: 17

1. The responsibility of a notary in a civil manner regarding the material truth of the Deed he makes, in the construction of acts against the law. Actions against the law here are active or passive.

a. Active, in the sense of committing an act that causes harm to other parties.

b. Passive, in the sense of not committing an act which is a must, so that the other party suffers a loss.

So the elements of an act against the law here are the existence of an act against the law, an error and the loss caused. Actions against the law here are broadly defined, namely an act not only violates the law, but also violates the appropriateness, decency or rights of others and causes harm. An act is categorized as an act against the law if the act:

\footnotetext{
${ }^{14}$ Oting Supartini, Anis Mashdurohatun, Legal Consequences of Credit Agreement Deeds Made by Notaries with Guarantee of Mortgage There is Legal Certainty and Justice for the Parties, Journal of Legal Reform Volume III No. May 2 - August 2016, p. 202
} 
a. Violating the rights of others.

b. Contrary to the perpetrator's legal obligations

c. Contrary to decency.

d. Contrary to appropriateness in paying attention to the self-interest and property of others in daily life.

The responsibilities of a notary in the realm of civil law, including taxation responsibility, are additional notary powers granted by the Taxation Law.

2. The responsibility of the Notary Criminally regarding the material truth in the Deed he makes. Criminal in this case is a criminal act committed by a notary in his capacity as a public official who is authorized to make deeds, not in the context of an individual as a citizen in general.

Referring to the prevailing regulations, it is known that a notary public can be held responsible for a criminal responsibility in the case of making deeds based on false information, and the rules relating to the above issues are Article 263 paragraph (1), 264 paragraph (1) 1st, or 266 paragraph (1) of the Criminal Code jo. Article 55 paragraph (1) of the Criminal Code. Meanwhile, the UUJN provisions do not regulate criminal acts committed by notaries.

3. The responsibility of a Notary based on the Notary Position Regulation regarding the correctness of the material in the Deed he makes.

4. The notary's responsibility in carrying out his/her job duties is based on the Notary's code of ethics.

In the world of banking, a notary has a duty which is also the authority to make legal actions which are generally administrative in nature. In the act itself, the notary can make various kinds of contracts or agreements regarding credit or borrowing and lending, buying and selling, leasing, minutes of auction and contracts required by the parties. Of course, Notaries must also adhere to the standards of making agreements according to the Law.

Basically, the process of implementing a credit agreement in general in banking is as follows:

1. The existence of an offer letter for a notary work or better known as an offering letter from a bank which contains what things are desired in the implementation of the credit agreement, for example regarding the type of credit, the amount of the credit limit given, interest rates, guarantees, tenure, and implementation of the signing of the credit deed. This offering letter has a legal basis in the internal regulations of each bank. 
2. The notary reads and pays close attention to the things he wants in the offering letter, then asks for the completeness of the documents that will be used as the substance of the credit agreement, for example a photocopy of the credit agreement between the bank and the parties, the original guarantee, if it is a certificate to be checked at the land office, the identity of the parties, and other file completeness.

3. After the stipulated time, the notary together with the parties will sign the credit agreement deed by doing so according to the applicable procedures and provisions as in Act No. 2 of 2014 concerning Amendments to Act No. 30 of 2004 concerning the Position of Notary Public.

4. After the signing is complete, the notary gives a letter which is generally known as a covernote. In general, this covernote is a letter that contains the period for the completion of all notary obligations to deeds or written administrative legal actions that will be completed by the notary concerned. This Covernote is not a letter that guarantees that all legal events that have been carried out will not be hampered later because in the process of completing all components of the credit agreement, for example the installation of security rights against collateral in the form of certified land, there could be legal interference from third parties that make the notary unable. carry out its authority as the party that will carry out the matter. The disturbance was certainly not influenced by a notary, but it could be from the bank or the debtor. This is something to remember about the essence of covrnote. In addition to this covernote, the notary provides a guarantee receipt or other important documents to the bank if the important files have been given to the notary so that the administration will run properly.

5. After all the work of the notary has been carried out, the notary is obliged to withdraw the original covernote and make a new receipt that all files that have been received by the notary have been returned to the bank.

Based on the description above, the author is of the view that a notary should not be separated from the responsibilities that should be carried out. The theory of responsibility emphasizes the meaning of responsibility born from the provisions of the Prevailing Laws so that the theory of responsibility is interpreted in the sense of liabilty, as a concept related to the legal obligation of a person who is legally responsible for certain actions that he or she can be subject to a sanction in the case his actions are against the law.

Notaries who sign bank credit agreements still pay attention to the provisions of laws and regulations so as not to deviate from the Notary's code of ethics. Notary is able to be responsible for what he has done as a form of professionalism in carrying out his position. 


\section{Closing}

The validity of a bank credit agreement is adjusted to the legal terms of the agreement according to Article 1320 of the Civil Code, namely agreement, competence, lawful causes, and certain matters. Each credit that has been agreed upon must be stated in the credit agreement in writing. The form and format shall be submitted by Bank Indonesia to the respective bank to determine it, however in safeguarding measures, at least it must pay attention to the following matters: Fulfilling the legality and legal requirements that can protect bank interests and Contain the amount, period, procedure credit repayment and other credit terms as stipulated in the said credit approval decision. The responsibility of a notary to the parties if in the process of signing a credit agreement it cannot be carried out in accordance with the rules of the Notary Office, as it is known that the notary is not an interested person in the credit agreement, a notary is only someone who in his profession is neutral in nature who tells the parties what to do. Thus, the notary's responsibility is limited to the process of implementing the credit agreement, only to the actions taken whether it is in accordance with the procedure or not, not to the administrative nature. a notary is just someone who in his profession is neutral who tells the parties what to do. Thus, the notary's responsibility is limited to the process of implementing the credit agreement, only to the actions taken whether it is in accordance with the procedure or not, not to the administrative nature. a notary is just someone who in his profession is neutral who tells the parties what to do. Thus, the notary's responsibility is limited to the process of implementing the credit agreement, only to the actions taken whether it is in accordance with the procedure or not, not to the administrative nature.

Notaries must stick to and be able to carry out their duties based on existing and future legal regulations related to their profession, so that notaries can avoid legal problems that can plunge themselves. Notaries should be able to carry out and carry out their duties and functions in accordance with standard operating procedures (SOPs) so that the agreement signing process can be accounted for by law.

\section{References}

Journals:

[1] Gunarto Suwandi, 2006, Resiko Dalam Pemberian Kredit Perbankan, Jurnal Hukum Projustitia. January 2006, Volume 24 No. 1.

[2] Mariah Kamelia, Anis Mashdurohatun, Peran Notaris Dalam Pembuatan Akta Perjanjian Kredit Dalam Perspektif Hukum Positif Dan Hukum Islam, Jurnal Akta, ol. 4 No. 4 December 2017.

[3] Oting Supartini, Anis Mashdurohatun, Akibat Hukum Akta Perjanjian Kredit Yang Dibuat Notaris Dengan Jaminan Hak Tanggungan Adanya 
Kepastian Hukum Dan Keadilan Para Pihak, Jurnal Pembaharuan Hukum Volume III No. 2 May - August 2016

Books:

[1] Abdulkadir Muhammad. (2014). Hukum Perdata Indonesia, Cet V, Bandung: Citra Aditya Bhakti

[2] Ahmadi Miru and Sakka Pati. (2008). Hukum Perikatan: Penjelasan Makna Pasal 1233 Sampai 1456 BW, Cet III, Jakarta: Rajagrafindo Persada

[3] Elly Erawati dan Herlien Budiono. (2010). Penjelasan Hukum Tentang Kebatalan Perjanjian, Jakarta: PT Gramedia

[4] Herlien Budiono. (2013). Kumpulan Tulisan Hukum Perdata di Bidang Kenotariatan, Bandung: Citra Aditia Bakti

[5] Jamal Wiwoho and Anis Mashdurohatun. (2017). Hukum Kontrak, Ekonomi Syariah dan Etika Bisnis. Semarang: Undip Press

[6] Ratna Artha Windari. (2014). Hukum Perjanjian. Yogyakarta: Graha Ilmu

[7] Soerjono Soekanto \& Sri Mamudji. (2001). Penelitian Hukum Normatif (Suatu Tinjauan Singkat). Jakarta: Rajawali Pers

[8] Sri Sumawarni. (2012). Sebuah Seri Metode Penelitian Hukum, Semarang: UPT UNDIP Press

[9] Wirjono Prodjodikoro. (2000). Perbuatan Melanggar Hukum, Bandung: Mandar Maju, Bandung 